\title{
Tengo una idea de negocio. ¿Ahora qué?
}

\section{I have a business idea. Now what?}

Ing. Héctor Neira Rivera Ms.C.

Universidad Internacional del Ecuador, Ecuador

Ing. Eduardo Viteri

Co-fundador Startup boys, Ecuador

Autor para correspondencia: eduardovf92@gmail.com; hneira@gmail.com

Fecha de recepción: 08 de Marzo de 2016 - Fecha de aceptación: 15 de Mayo de 2016

\section{Resumen}

Esta es tal vez la pregunta más frecuente que toda persona se hizo al tener alguna vez una potencial idea de negocio. Hay muchas maneras de emprender, aquí te ayudaremos con una guía basada en los métodos que utilizan las grandes empresas de tecnología de Silicon Valley y alrededor del mundo para llegar a donde están.

Palabras claves: emprendimiento; negocios; motivación

Abstract: This is perhaps the most frequent question that everyone was to ever have a potential business idea. There are many ways to undertake here will help you with a guide based on the methods used by large technology companies in Silicon Valley and around the world to get where they are.

Key words: entrepreneurship; business; motivation 


\section{Introducción}

\section{Identifica un problema}

Vender es ciencia y arte. Pero una de las maneras más fáciles de vender es la de proveer una solución a un problema grande que tengan las personas, compañías o nicho marcado. Es muy común encontrar soluciones a problemas que nadie tiene, así que asegúrate que este sea real y experimentado por más de un usuario.

Cuando tengas una idea, pregúntate: ¿Quién necesita esto ahora? ¿Quién pagaría dinero para obtener mi solución? Si te cuesta mucho encontrar una respuesta a estas preguntas entonces es probable que tu idea no sea muy buena.

Sentado en tu casa hace más difícil observar potenciales problemas. Sal y experimenta el mundo, haz amigos y construye cosas. Conviértete en esa persona que experimente ese particular problema, de esta manera podrás identificar con más eficiencia una solución.

\section{Identifica soluciones para el problema}

Has identificado un problema experimentado por más de un usuario. Para poder identificar la solución más óptima, es muy importante ponerte en los zapatos de los que experimentan este problema. ¿Cuál es la manera más rápida de solucionar este problema? Tu solución puede fracasar si no brindas la solución que ellos buscan.

Una excelente forma es preguntarles directamente a estos usuarios como quisieran solucionar este problema o proponer tu solución y preguntar qué opinan. Aprende todo lo que puedas sobre estos usuarios, vuélvete un experto de la industria.

Lograr identificar una solución eficiente para el problema es crítico, ya que un buen producto se vende solo. Tu principal objetivo debe ser que tu solución traiga uno o más beneficios marcados a tus usuarios, estos pueden ser: rapidez, mejor precio, más sencillo, incremento de ventas, facilidades, etc. Si logras solucionar el problema de una manera sencilla y con beneficios claros, estos usuarios se convertirán en tu mejor fuente de publicidad, ya que le comentarán sobre tu solución a otros usuarios que experimentan este tipo de problema.

Construye algo que alguien quiera y necesite, no resuelvas un problema que tú crees que la gente tiene, resuelve un problema que tú sabes que la gente tiene. Las ideas son como lo mosquitos, están por todos lados, lo que hace la diferencia es la ejecución. Ejecuta una solución eficiente para tu problema, haz que tus usuarios te amen, y es muy probable que tengas mucho éxito.

\section{Construye un prototipo}

En tu mente ya has visualizado a tu producto con muchas características beneficiosas para el usuario, un producto perfecto, como si fuera concebido por el mismo Steve Jobs. Ser 
perfeccionista como Steve es bueno pero en la realidad esto es muy poco práctico y hará muy ineficiente el proceso.

Para hacer el proceso de construcción más eficiente, vas a enfocarte en las cualidades mínimas que deba tener tu producto para poder resolver el problema. A este lo llamaremos el producto mínimo viable (PMV).

Construir un PMV hace el proceso más eficiente por varios motivos. Vas a poder sacar más rápido tu producto al mercado y obtendrás feedback de tus clientes. Esta información es invaluable, ya que con esta misma se validará tu hipótesis y podrás continuar añadiendo los beneficios adicionales que tenías pensado. Si los usuarios no adquieren tu producto entonces sabrás que tu hipótesis estuvo incorrecta y habrás ahorrado mucho tiempo y dinero en construir algo que nadie quería en primer lugar.

Teniendo tu producto en el mercado hará más fácil el proceso de mejoramiento del producto. Cuando tus clientes adquieran e interactúen con tu producto generarán mucha información que, si sabes utilizarla a tu favor, podrás iniciar con el procedo de optimización del producto. Esto es, sabrás que beneficios y características extra añadirle y que características actuales debes cambiar o eliminar.

Recuerda la solución en la que pensaste y pregúntate ¿Cuáles son las características mínimas que mi producto debe tener para resolver este problema? Estas características deben de tener como función principal resolver el problema y nada más. Una vez que empieces a obtener información de tus clientes puedes empezar a agregar esas características extras que harán de tu producto digno de los laboratorios de Apple.

\section{Test}

Es hora de sacar tu PMV al mercado. Pero, ¿a quién lo ofrezco? y ¿cómo lo hago? Pues ya tienes identificados a los usuarios que están dispuestos a comprar tu solución. Una forma muy común de vender tu PMV es la de contactar directamente a estos usuarios, ya sea vía correo electrónico, una llamada o mejor aún, cara a cara. Un correo puede ser algo tan simple como: "Hola, he construido una solución para este tipo de problema y funciona de tal forma. Si estás interesado contáctame a mi celular y nos tomamos un café. Saludos"

Hoy en día la publicidad altamente dirigida que permiten realizar las redes sociales también nos permite encontrar potenciales clientes por un bajo precio. Identifica los intereses en común que tus clientes tengan y pon una publicidad por unos dólares.

Si tu PMV ayuda a alguna industria o nicho claramente marcada, entonces una buena táctica es la de identificar a las personas, medios o negocios que se consideran autoridades dentro de esta industria y ofrecerles tu producto. Si tu producto es bueno, estas autoridades se encargarán de comentar a otros usuarios sobre tu solución dándote una publicidad de efecto viral.

Una vez que hayas tenido algunas ventas es sumamente importante recopilar información. Esta es tal vez la actividad más importante dentro del ciclo estudiado, ya que con esta 
información validarás o rechazarás tu hipótesis inicial. También sabrás que características extras requieren los usuarios y cuales están de sobra.

Si la información recopilada es positiva, es decir, tus usuarios están contentos con la solución proveída entonces tu hipótesis ha sido confirmada, ¡felicitaciones! Ahora es el momento de invertir más y expandirse.

Si el feedback es negativo, debes analizar cuál es la razón. Si los usuarios no están contentos con el producto provisto debes preguntarte si tu producto en realidad está solucionando el problema o no está cumpliendo su función.

Si el feedback es neutro, entonces es muy probable que ciertas características de tu producto sean de utilidad y otras no. Si este es el caso entonces ha llegado el momento de pivotear, es decir, cambiar ligeramente el enfoque de tu producto pero manteniendo las bases.

Esta información proveída por los usuarios es quizás la más importante para tu negocio. Debes profundizar y analizar esta data lo mejor posible, ya que te permitirá perfeccionar tu producto y ofrecer cada vez uno mejor. Una vez identificado lo que quieren los usuarios de tu producto, crea la siguiente versión y vuelve a sacar al mercado que tienes identificado. Sigue en este ciclo de prototipo-test-optimización hasta que tengas un producto increíble y que tus usuarios amen.

\section{Conclusión y Motivación}

Esta es tan solo una metodología para emprender y probar una nueva idea. Pero si la realizas bien, es una metodología poderosa que te permitirá probar tu hipótesis por una cantidad limitada de dinero y tiempo. La idea fundamental de emprender es la de transformar una idea en un producto, ya sea este un producto físico, software o servicio. Descubre que es lo que la gente quiere y necesite. Resuelve una necesidad con una solución eficiente y tendrás un producto que la gente ame.

\section{Bibliografía}

Knapp, J. (2016). Sprint: How to solve big problems and test new ideas in just five days. Ealing: Bantam Press.

Ries, E. (2011). The lean startup. New York: Crown Business. 